Kredo 4 (2021)
KREDO: Jurnal Ilmiah Bahasa dan Sastra
Terakreditasi Sinta 4 berdasarkan Keputusan Direktorat
Jenderal Penguatan Riset dan Pengembangan,
Kementerian Riset, Teknologi dan Pendidikan Tinggi
Republik Indonesia
Nomor: 23/E/KPT/2019. 08 Agustus 2019
https://jurnal.umk.ac.id/index.php/kredo/index

\title{
PEMETAAN MATERI SASTRA DALAM BUKU PELAJARAN BAHASA INDONESIA SEKOLAH MENENGAH PERTAMA
}

\author{
Miftakhul Huda, Uswatun Khasanah, Vitria Indriyani Setyaningsih \\ miftakhul.huda@ums.ac.id
}

Universitas Muhammadiyah Surakarta, Indonesia

Info Artikel

Sejarah Artikel

Diterima

20 Februari 2021

Disetujui

22 Februari 2021

Dipublikasikan

6 April 2021

Keywords

literary teaching

materials, textbook

\section{Kata Kunci}

buku pelajaran, materi ajar sastra, pemetaan materi
:

: $\quad$ This study aims to describe the mapping of literary material in Indonesian secondary school textbooks. This type of research is qualitative. It is used to solve existing problems based on data that has been obtained, described, analyzed, and concluded. The data used in this research is in the form of literary materials contained in literature lessons and the suitability or complexity of the literary materials of lessons in Indonesian language textbooks at junior high school level. The source of data in this study is the Indonesian language textbook for junior high school level published by the 2017 revised edition of the Ministry of Education and Culture. The data collection technique uses observation and note-taking techniques. In this study, qualitative interactive analysis techniques were used, there are several stages, namely data reduction, data presentation (data display), conclusions, and verification. In this study, it can be concluded that the literary material in Indonesian language textbooks published by the Ministry of Education and Culture for

: the seventh grade junior high school level consists of fantasy stories, folk poetry, and fables. Class VIII consists of poetry, short stories, plays, and fiction. Class IX consists of text exemplum. Literary material in junior high school Indonesian language textbooks is 8 out of a total of 26 materials. Thus, the literary material in Indonesian language textbooks has a percentage of $37,8 \%$.

Abstrak
Penelitian ini bertujuan memaparkan pemetaan materi sastra dalam buku pelajaran Bahasa Indonesia Sekolah
Menengah Pertama. Jenis penelitian ini kualitatif. Hal tersebut digunakan untuk memecahkan masalah yang
ada berdasarkan data-data yang sudah diperoleh, dideskripsikan, dianalisis, dan disimpulkan. Data yang
digunakan dalam penelitian ini berupa materi-materi sastra yang terdapat dalam pelajaran sastra dan
kesesuaian atau kompoleksitas materi-materi sastra pelajaran pada buku teks Bahasa Indonesia jenjang SMP.
Sumber data dalam penelitian ini yaitu buku teks Bahasa Indonesia jenjang SMP diterbitkan oleh
Kemendikbud edisi revisi 2017. Teknik pengumpulan data menggunakan teknik simak dan teknik catat.
Dalam Penelitian ini digunakan teknik analisis interaktif kualitatif, terdapat beberapa tahapan, yaitu reduksi
data (data reduction), penyajian data (data display), dan kesimpulan, serta verifikasi. Penelitian ini dapat
disimpulkan bahwa materi sastra dalam buku pelajaran Bahasa Indonesia terbitan Kementerian Pendidikan
dan Kebudayaan untuk jenjang Sekolah Menengah Pertama kelas VII terdiri dari cerita fantasi, puisi rakyat,
dan fabel. Kelas VIII terdiri dari puisi, cerita pendek, drama, dan fiksi. Kelas IX terdiri dari teks eksemplum.
Materi sastra dalam buku pelajaran Bahasa Indonesia Sekolah Menengah Pertama berjumlah 8 dari jumlah
total 26 materi. Dengan demikian, materi sastra dalam buku pelajaran Bahasa Indonesia memiliki persentase
sebanyak 37, 8\%.




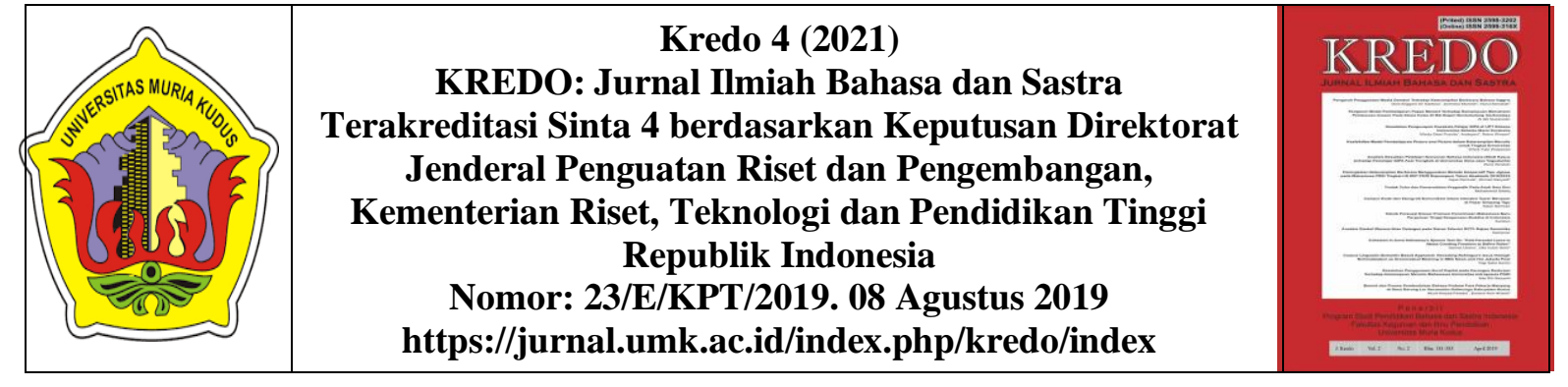

\section{PENDAHULUAN}

Pembelajaran sastra di sekolah tidak berdiri sendiri sebagai mata pelajaran yang mandiri, tetapi menjadi bagian dari mata pelajaran Bahasa Indonesia dan Sastra Indonesia (Huda, Markhamah, and Sabardila 2011). Pada cakupan materi pelajaran sastra berbeda setiap jenjang pendidikan. Dari berbagai problematika yang dihadapi siswa di sekolah, muncul beberapa hal yang dianggap siswa untuk dilakukan dalam meningkatkan pembelajaran sastra (Huda 2018), (Huang 2017), (Tabatadze and Gorgadze 2016). Tidak sedikit siswa kurang memahami materi kesastraan dengan baik, siswa merasakan bosan dan tidak tertarik dengan materi pelajaran. Keluhan guru tentang sulitnya materi sastra juga dapat menjadi masalah yang bisa dikemukakan (Ranker 2019), (Darvin 2018), (Barnes and McCallops 2019). Faktor yang biasanya terjadi yakni fasilitas yang kurang mendukung yang menyebabkan siswa kurangnya minat siswa mempelajari materi kesastraan. Dalam dunia pendidikan di Indonesia, tidak lepas dari sebuah kurikulum yang mencakup beberapa hal penting salah satunya mata pelajaran yang harus ditempuh oleh siswa sebagai suatu program pelajaran. Pemerintah Indonesia saat ini tengah fokus mengatasi kualitas pendidikan yang dianggap oleh banyak kalangan masih rendah. Adanya kurikulum dalam pendidikan dianggap sangat penting.

Pada kurikulum di Indonesia mengalami banyak perubahan untuk mencukupi segala kebutuhan belajar siswa serta meningkatkan kualitas pendidikan di Indonesia yang tentunya perubahan tersebut artinya harus memperbaiki pelaksanaan kurikulum sebelumnya. Pada tahun 2013/2014 Kementrian Pendidikan Nasional Indonesia menyepakati perubahan kurikulum baru pada dunia pendidikan di Indonesia, yaitu Kurikulum 2013. Kurikulum 2013 menekankan pada pengembangan kompetensi pengetahuan, keterampilan, dan sikap siswa secara holistik atau seimbang (Huda 2019b). Kurikulum 2013 dibuat sebagai strategi peningkatan mutu pendidikan di Indonesia untuk menyeimbangkan antara kompetensi sikap, keterampilan, dan pengetahuan dengan menekankan aspek kognitif, afektif, dan psikomotor. Perubahan tersebut tentunya mengubah beberapa komponen pembelajaran dalam pendidikan. Salah satunya pada penggunaan buku pelajaran yang digunakan untuk media dalam proses pembelajaran.

Buku teks pelajaran merupakan sumber belajar dan media yang sangat penting untuk mendukung tercapainya kompetensi yang menjadi tujuan pembelajaran. Pemilihan dan pemanfaatan buku teks sebagai media sumber pembelajaran yang tepat merupakan faktor pendukung keberhasilan dalam pembelajaran (Huda and Pratiwi 2020). Buku pelajaran adalah salah satu bagian dari perangkat pembelajaran yang digunakan untuk memacu, memajukan, serta meningkatkan kecerdasan bagi pembacanya. Di dalam suatu buku pelajaran tidak lepas dengan adanya materi ajar. Adanya materi ajar dalam suatu buku pelajaran memiliki peranan penting sebab, materi ajar adalah tolak ukur dalam pencapaian suatu tujuan pembelajaran (Huda, Kustanti, and 


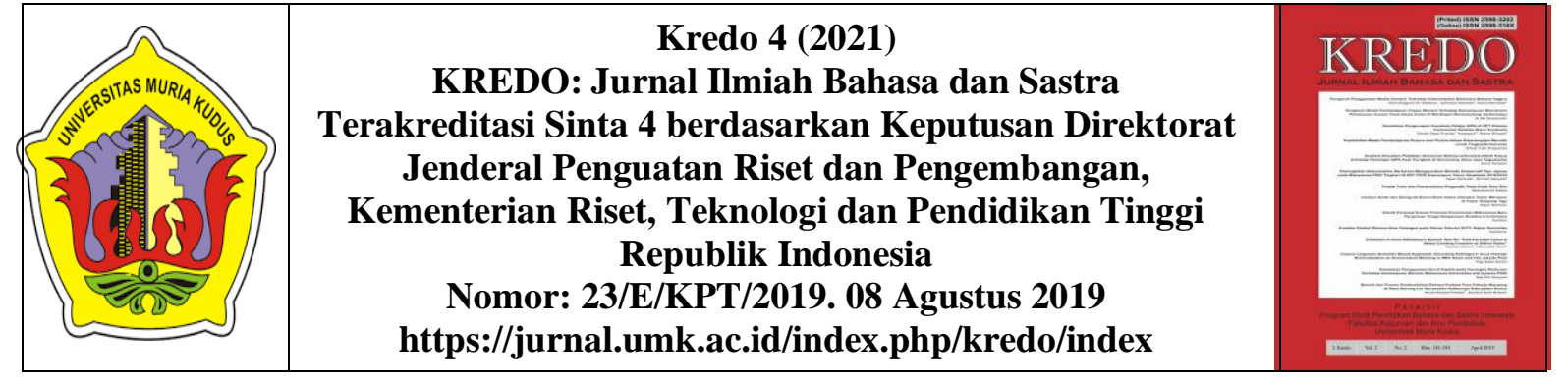

Rufiah 2019), (Thi Nguyen 2020), (Moto et al. 2018).

Pembelajaran Bahasa Indonesia sendiri memiliki kedudukan yang cukup penting dalam kurikulum 2013. Pada kurikulum ini buku pelajaran Bahasa Indonesia mencakup materi sastra yang memiliki persentasi sedikit dibandingkan dengan materi bahasa. Dalam buku pelajaran bahasa Indonesia dapat mencakup materi ajar bahasa dan sastra. Namun, pada kenyataannya pembelajaran Bahasa Indonesia umumnya didominasi oleh materi nonsasastra. Hal tersebut juga membuat beberapa teori dalam materi sastra dalam buku pelajaran bahasa Indonesia tergolong sedikit.

Materi sastra yang terdapat dalam buku tersebut meliputi prosa, puisi, dan drama. Sastra merupakan ungkapan pribadi manusia berupa pengalaman, pemikiran, perasaan, gagasan, semangat, keyakinan dalam suatu bentuk gambaran konkret yang membangkitkan pesona dengan alat-alat bahasa (Lo 2017), (Muakibatul Hasanah 2012). Kinasih (2018) meneliti "Muatan Materi Sastra dalam Buku Teks Bahasa Indonesia Kelas VIII Serta Relevansinya dengan Kompetensi Inti dan Kompetensi Dasar" yang memuat berupa (a) materi sastra yang disajikan dalam buku teks ini berupa puisi, prosa yang meliputi novel, ulasan film, ulasan lagu, cerita pendek, dan drama, (b) relevansi materi sastra dengan kompetensi inti disajikan beberapa pokok bahasan materi sastra yang dikatakan relevan karena memberikan kegiatan tugas siswa dan penjelasan yang memadai kemudian terdapat beberapa pokok bahasan materi sastra yang tidak relevan karena tidak fokus memberikan penjelasan dan kegiatan yang memadai untuk tercapainya kompetensi inti, dan (c) relevansi materi sastra dengan kompetensi dasar disajikan beberapa pokok bahasan materi sastra relevan dengan kompetensi dasar dan sebanyak beberapa pokok bahasan materi sastra yang tidak relevan dengan kompetensi dasar.

Materi sastra yang terdapat pada buku pelajaran memiliki sebuah pesona apabila hendak membacanya. Sastra tersebut dapat membuka pengetahuan realitas sosial, politik, serta budaya dalam moral dan etika (Huda 2020), (Rahmouni and Abdulaziz 2020), (Liu et al. 2020). Sastra dalam buku pelajaran dapat dimanfaatkan sebagai alat untuk meningkatkan kepekaan siswa terhadap nilai-nilai kehidupan dan kearifan dalam menghadapi lingkungan, realitas kehidupan, dan sikap pendewasaan (Huda 2019a), (Subyantoro 2007). Melalui pembelajaran sastra, diharapkan siswa tumbuh menjadi manusia dewasa yang berbudaya, mandiri, sanggup mengekspresikan diri dengan pikiran dan perasaannya dengan baik, berwawasan luas, dan kritis. Sastra merupakan sarana untuk mengkaji nlai-nilai yang memuat akhlak, moral, pendidikan, dan religi. Materi sastra dalam buku pelajaran selain meningkatkan kepekaan rasa dan menambah wawasan dan pengetahuan didunia pendidikan serta masyarakat umum. Sastra dalam buku pelajaran memiliki implementasi dalam pembelajaran masih cukup kurang. Materi sastra dengan materi kebahasaan pada kurikulum 2013 menyatu menjadi satu, dalam arti: (a) melalui teks genre sastra dapat diajarkan ciri-ciri kebahasan suatu teks, dan (b) dalam kegiatan mengonversi teks, pemanfaatan teks 


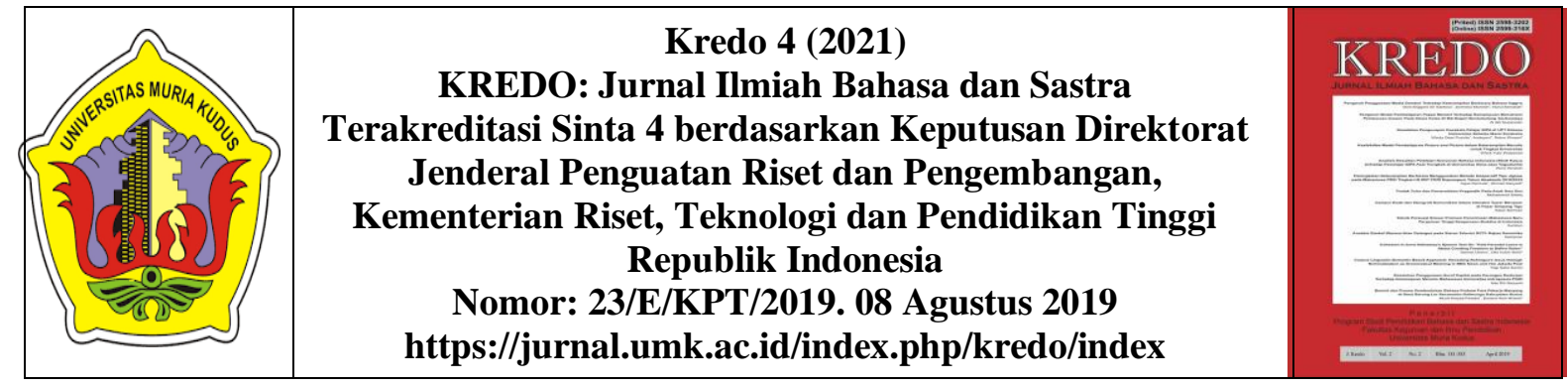

sastra sangat menguntungkan. Berawal dari teks sastra kemudian dikonversi menjadi berbagai teks, baik teks yang termasuk dalam teks sastra maupun teks nonsastra.

Materi sastra yang disampaikan tidak hanya menekankan aspek kebahasaan saja, lebih baik dalam pemilihan bahan ajar sastra harus mempertimbangkan beberapa aspek (Huda, Syukur, and Siswanto 2020), (Israfilov, Borisova, and Kartashova 2020), (Malluhi and Alomran 2019). Dalam buku pelajaran Bahasa Indonesia, pemahaman siswa mengenai teks sastra juga terpenuhi dengan adanya materimateri sastra yang diberikan secara kompleks melalui teori-teorinya. Pemahaman pengajaran materi sastra sekolah juga masih kurang maksimal karena teori yang disampaikan dalam materi sastra hanya menjelaskan pengertian karya sastra dan unsur-unsur intrinsiknya tanpa meminta membaca dan memahami karya yang dikaji. Pembelajaran sastra yang dilaksanakan tidak terlepas dari teori sastra yang melatarbelakangi. Teori sastra hadir dalam pembelajaran sastra melalui karya sastra yang dihadirkan. Teori sastra mempelajari pandangan orang terhadap sastra. Teori sastra juga menjadi semacam alat-alat para intelektual atau ilmuwan dalam bidang sastra untuk memperlakukan sastra itu sendiri. Melihat begitu pentingnya materi sastra dalam buku pelajaran Bahasa Indonesia, sudah semestinya bahwa cakupan teori pada muatan materi sastra misalnya puisi, drama, dan prosa harus diberikan secara kompleks atau lebih mendalam, agar pemahaman materi sastra yang dimiliki oleh siswa bukan hanya mengenai gambaran-gambaran umum saja, tetapi siswa juga mampu mendalami teks sastra secara kompleks. Teori sastra mencakup teori sastra secara khusus yang terdapat dalam teks sastra, yaitu teks anekdot, teks cerpen, teks pantun, teks ulasan film/ drama dan teks novel. Teori sastra yang mendominasi Kurikulum 2013 adalah teori objektif, yakni terfokus pada struktur karya sastra. Jika dilihat dengan seksama, pada kurikulum terbaru ini, muatan materi sastra yang terdapat dalam buku siswa masih belum mendalam. Misalnya pada materi puisi, jika dalam satu buku pelajaran Bahasa Indonesia hanya memuat gambaran umum seperti strukturnya dan di dalamnya hanya memuat satu teori saja, maka dapat diasumsikan bahwa muatan teori sastra pada teks puisi dalam buku pelajaran Bahasa Indonesia tersebut masih kurang. Teori sastra sangat dibutuhkan dalam kedua bidang lainnya, yaitu sejarah sastra dan kritik sastra. Penyelidikan tentang sejarah sastra banyak memerlukan bahan pengetahuan tentang teori sastra.

Berdasarkan uraian tersebut, peneliti mengkaji mengenai pemetaan materi sastra dalam buku siswa khususnya mata pelajaran Bahasa Indonesia. Materi ajar yang terdapat dalam buku pelajaran sangatlah penting untuk diteliti sebab buku teks merupakan sumber utama siswa dalam mencapai suatu kompetensi dasar. Mengenai permasalahan cakupan teori materi sastra, dalam buku pelajaran Bahasa Indonesia dijadikan tolak ukur adanya perubahan yang lebih baik dalam penyusunan kompetensi dasar dan buku ajar pada mata pelajaran Bahasa Indonesia. 


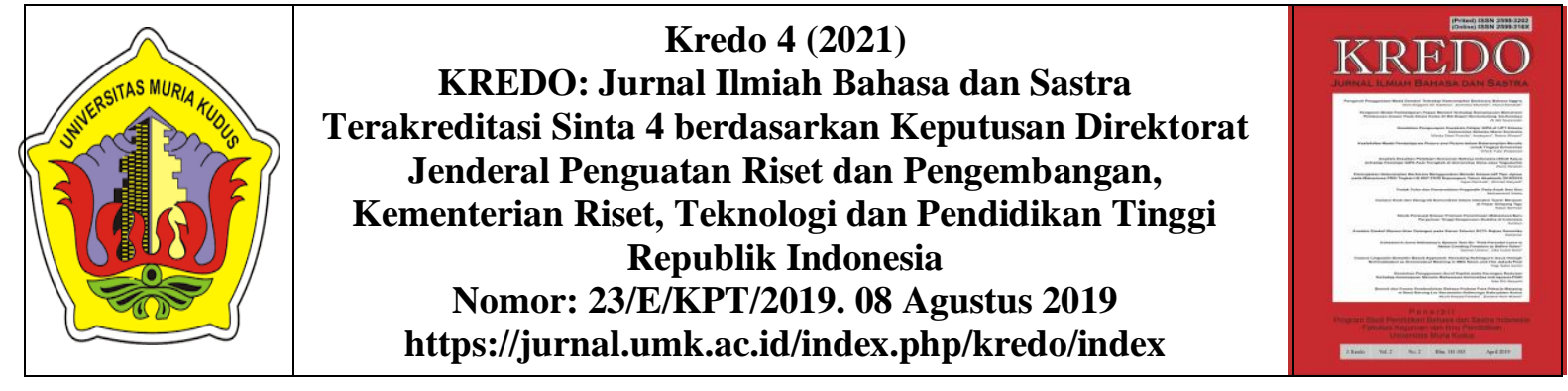

\section{KAJIAN TEORI}

\section{Urgensi Buku Teks di dalam Pembelajaran}

Buku teks merupakan media yang berperan untuk menyampaikan materi pelajaran dalam suatu kurikulum pendidikan yang digunakan oleh guru dan siswa dalam kegiatan belajar mengajar (KBM). Penyusunan buku teks juga memuat sesuai dengan standar kurikulum yang sudah disusun (Bezemer and Kress 2008), (Bogodistov, Botts, and Schlatterer 2019). Peran buku teks sebagai media pembelajaran digunakan oleh guru untuk memberikan materi pelajaran kepada siswa (Huda and Pratiwi 2020). Buku teks adalah penjabaran dari isi kurikulum secara operasional. Penetapan buku teks adalah salah satu buku yang wajib digunakan oleh siswa juga diatur dalam Permendikbud No. 71 Tahun 2013 sebagai sumber yang layak bagi siswa. Adanya buku teks atau modul diharapkan dapat menjadi sarana pemberian materi kepada siswa.

Pembuatan buku ajar seharusnya disusun sebaik-baiknya agar mampu 1) meningkatkan kegiatan pembelajaran, 2) terselenggaranya proses maju berkelanjutan secara efektif, 3) pembelajaran berpusat pada siswa (Huda 2019b). Berkaitan dengan buku teks di dalamnya juga terdapat materi ajar yang hendak disampaikan kepada siswa agar memahami materi-materi sesuai dengan standar kompetensi serta indikatorindikator yang sudah ditetapkan. Buku teks atau bisa disebut dengan modul mampu meningkatkan pembelajaran dan memberikan keterlibatan pengajar dan pembelajaran. Hal ini juga dijelaskan oleh Ilyas (2015) yang menjelasan bahwa buku teks dapat digunakan untuk siswa sekolah, mengatakan bahwa buku teks sekolah dapat digunakan di Indonesia membutuhkannya lebih banyak kegiatan yang mampu mendorong pemikiran yang kritis.

Buku pelajaran sangat berperan penting penunjang program pembelajaran. Kedudukan buku teks pelajaran sangatlah penting, bagi siswa-siswa maupun guru. Tingkat kepentingan buku pelajaran haruslah layak digunakan sebagai simpanan pengetahuan berbagai segi kehidupan. Penggunaan buku pelajaran oleh siswa merupakan bagian yang dapat dari masyarakat yang maju. Buku teks pelajaran diperuntukkan bagi siswa, guru pun terbantu. Pada saat kegiatan belajar mengajar, guru juga terbantu dengan adanya buku teks sehingga guru mampu memiliki kebebasan dalam mengembangkan dan menyajikan materi pelajaran.

\section{Struktur Materi Ajar}

Dalam buku teks, materi ajar berperan penting dalam menunjang tercapainya tujuan pembelajaran. Materi ajar adalah sumber utama dalam suatu pembelajaran (Barnes and McCallops 2019), (Marcus et al. 2019). Materi ajar memuat pengetahuan, sikap, dan keterampilan yang harus dipelajari oleh siswa sebagai sarana tercapainya indikator yang sudah disusun dalam standar kompetensi dasar (Huda, Syukur, and Siswanto 2020), (Zhdanko 2019), (Moto et al. 2018). Dalam menyusun suatu materi ajar dalam buku teks hendaknya benar-benar diperhatikan agar menunjang tercapainya kompetensi dasar. Materi pembelajaran adalah suatu kombinasi materi pelajaran yang disusun secara sistematis meliputi unsur-unsur manusiawi, material, fasilitas, 


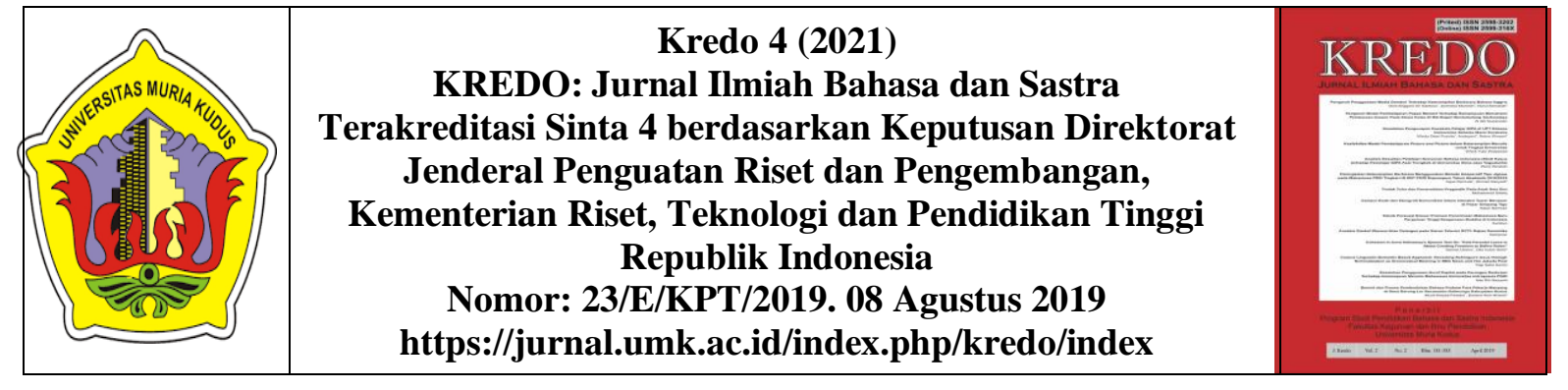

perlengkapan dan prosedur yang saling mempengaruhi untuk mencapai tujuan pembelajaran. Materi pembelajaran berisi beberapa komponen yang tersusun secara sistematis dan materi pembelajaran mengandung inti dari proses belajarmengajar yang disampaikan kepada siswa yang disusun sebagai materi ajar dalam pembelajaran apresiasi sastra adalah materi ajar yang merujuk pada pandangan modern (Martínez and Tadeu 2018), (Jalil, Ma'rof, and Omar 2019).

Materi ajar disusun bukan untuk dijadikan tujuan, melainkan sebagai sumber belajar bagi siswa yang diharapkan memiliki budaya komunikatif tinggi dan memberikan nilai yang positif agar tujuan dari pembelajaran dapat tercapai secara maksimal (Collette and Miller 2018), (Mudiono 2019). Berkaitan dengan materi ajar, salah satu aspek yang dibelajarkan dalam mata pelajaran Bahasa Indonesia, yakni materi pembelajaran sastra. Tujuan pembelajaran secara umum tersebut dijabarkan lagi dalam beberapa tujuan khusus. Tujuan khusus yang terkait dengan pengetahuan sastra, yaitu siswa dapat menikmati dan memanfaatkan karya sastra untuk memperluas wawasan, memperhalus budi pekerti, serta meningkatkan pengetahuan dan kemampuan berbahasa. Selain itu, dari pembelajaran sastra siswa diharapkan dapat menghargai dan membanggakan sastra Indonesia sebagai khazanah budaya dan intelektual manusia Indonesia.

\section{Teori di dalam Materi Sastra}

Sastra memiliki komposisi makna masing-masing. Setiap pakar atau pengarang mengartikan sastra berbagai makna, sebab masing-masing pakar atau pengarang mengartikan sastra sesuai dengan asumsinya masing-masing untuk menambah makna dari sastra itu sendiri. Artinya, sastra merupakan sebuah pengalaman, pemikiran atau perasaan manusia yang kreatif, reaktif, dan produktif terhadap sekitarnya dengan media bahasa (Ranker 2019), (Neumann and Mcdonough 2014). Berdasarkan penjelasan tersebut, sastra dapat diartikan sebagai nilai-nilai pendidikan yang dapat dijadikan sarana untuk mendidik. Melalui bahan ajar yang telah disusun secara maksimal, nilai-nilai pendidikan dapat dimasukan dalam pembelajaran di kelas (Kurhila and Kotilainen 2020), (Lina 2020). Melalui sastra, selain mampu melatih imajinasi siswa, penggunaan materi sastra dapat digunakan sebagai media penanaman nilai pendidikan dan membentuk kreativitas siswa yang berakhlak mulia.

Sastra memiliki makna yang sangatlah luas, dengan penambahkan karya sastra yang dapat digunakan sebagai media atau sarana pendidikan yang mampu menumbuhkan nilai pendidikan karakter, diharapkan siswa mampu membentuk karakternya sesuai dengan apa yang diharapkan. Dalam mendidik anak, sastra memberikan peranan penting untuk mengembangkan aspek kognitif, afektif, dan psikomotor anak, serta mampu membentuk kepribdian, dan mengembangkan moral (Wibowo, 2013: 19-20), (Brooks 2016), (Tarman and Acun 2010). Seperti yang sudah dijelaskan sebelumnya bahwa sastra sangatlah memiliki nilai imajinasi. Pengalaman hidup, hubungan antar manusiamaupun dengan alam, dan hubungan kepada Sang Kuasa. Artinya, begitu pentingnya nilai sastra tersebut siswa mampu membentuk karakternya 


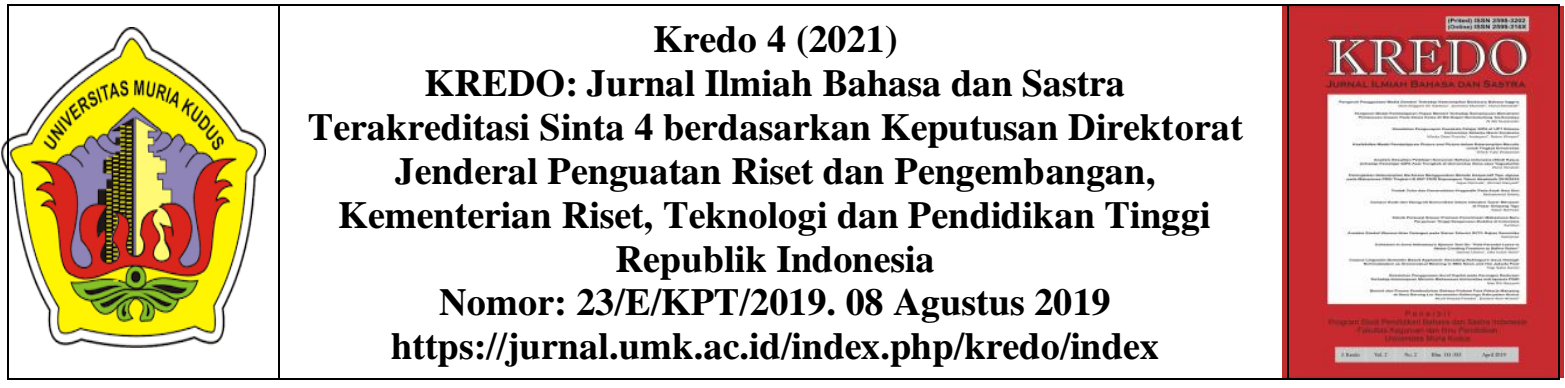

melalui teks sastra sebab pada dasarnya setiap aktivitas manusia mempunyai sikap dan karakter dalam menghadapi kehidupan. Imajinasi moral merupakan wahana pikiran dan hati untuk berani menyenangi, memimpikan, mengevaluasi, dan memilih akhir kehidupan yang baik (khusnul khotimah). Teks sastra memiliki banyak sekali jenisnya yang diajarkan kepada siswa yang masuk ke dalam kompetensi dasar (Haneda 2014), (Jessel et al. 2011).

\section{METODE PENELITIAN}

Jenis penelitian ini kualitatif. Deskripstif kualitatif adalah prosedur penelitian yang menghasilkan data berbentuk lisan atau tulisan, bukan data berupa angka. Hal tersebut digunakan untuk memecahkan masalah yang ada berdasarkan data-data yang sudah diperoleh, dideskripsikan, dianalisis, dan disimpulkan. Metode tersebut menggunakan sistem analisis dan bentuk hasil penelitian yang sudah diperinci. Penelitian ini dilakukan bertujuan untuk mendeskripsikan pemetaan materi sastra pada buku pelajaran Bahasa Indonesia. Data yang digunakan dalam penelitian ini berupa materi-materi sastra yang terdapat dalam pelajaran sastra dan kesesuaian atau kompoleksitas materi-materi sastra pelajaran pada buku teks Bahasa Indonesia jenjang SMP. Sumber data dalam penelitian ini yaitu buku teks Bahasa Indonesia jenjang SMP diterbitkan oleh Kemendikbud edisi revisi 2017.

Teknik pengumpulan data menggunakan teknik simak dan teknik catat. Teknik simak merupakan teknik yang digunakan seseorang atau beberapa informan dalam mendata data yang digunakan. Teknik Catat yaitu teknik lanjutan dari teknik simak yang dilakukan peneliti atau beberapa informan ketika menerapkan metode simak. Teknik simak dan teknik catat merupakan teknik yang digunakan peneliti atau beberapa informan sebagai instrumen kunci untuk melakukan penyimakan yang dilakukan secara cermat, terarah, dan teliti terhadap sumber data yang berupa buku teks Bahasa Indonesia jenjang SMP diterbitkan oleh Kemendikbud edisi revisi 2017.

Hasil penyimakkan dan pencatatan data yang sudah diperoleh digunakan dalam penyusunan penelitian. Kedua teknik ini digunakan untuk menjawab penelitian ini. Hal ini yang digunakan oleh peneliti untuk menyatukan data yang berupa materi sastra yang terdapat dalam buku Bahasa Indonesia di berbagai jenjang. Dengan demikian, penggunaan kedua teknik ini mampu mencapai tujuan penelitian

Analisis data dalam penelitian ini adalah proses mencari, menyusun serta menganalisis data yang diperoleh dari hasil wawancara secara sistematis sehingga mudah dipahami dan tentunya dapat diinformasikan kepada orang lain. Dalam Penelitian ini digunakan teknik analisis interaktif kualitatif, terdapat beberapa tahapan, yaitu:

\section{Reduksi data (data reduction)}

Mereduksi data berarti merangkum, memilah hal-hal pokok, dicari tema dan polanya. Tahapan reduksi data yang dilakukan oleh peneliti dilakukan dengan merangkum semua data yang telah diperoleh di lapangan dan memfokuskan pada hal-hal yang penting untuk dicari tema dan polanya melalui kegiatan penajaman dan penggolongan data. 


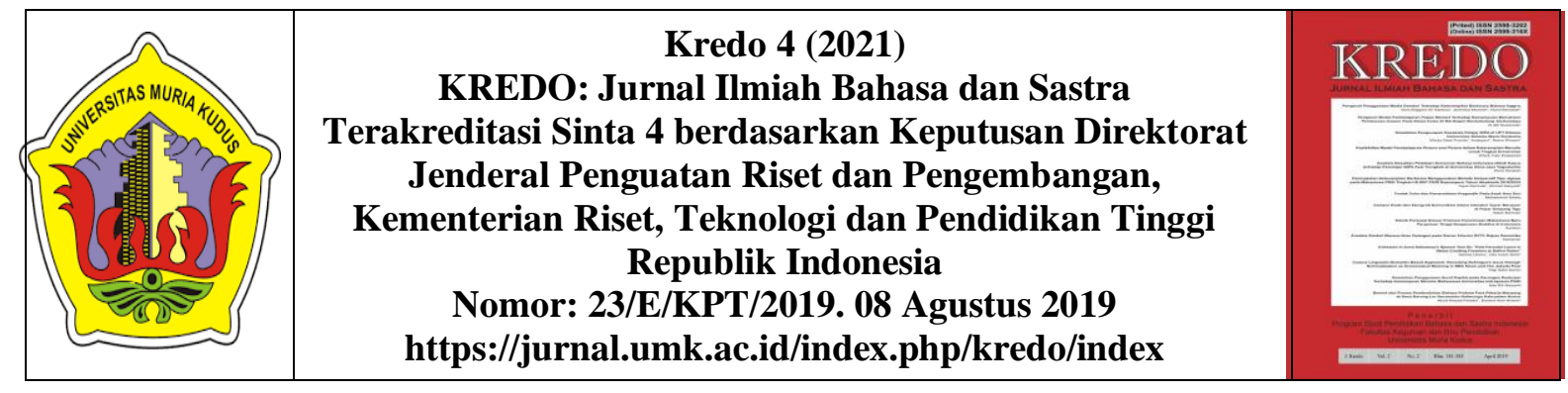

Penajaman dilakukan dengan mentrasformasi kata-kata dan kalimat yang panjang menjadi suatu kalimat yang ringkas dan penggolongan data dilakukan melalui pengelompokkan data sejenis dan mencari polanya dengan ditulis atau diketik dalam bentuk uraian. Reduksi data/ proses-transformasi ini berlanjut terus sesudah penelitian lapangan, sampai laporan akhir lengkap tersusun.

\section{Penyajian data (data display)}

Setelah data direduksi, maka selanjutnya adalah penyajian data. Penyajian data dilakukan dalam bentuk uraian singkat. Pereduksian data yang dilakukan oleh peneliti, dengan melakukan penyusunan data secara sistematis, dilanjutkan dengan penulisan data yang diperoleh di lapangan dalam bentuk naratif. Penyusunan dilakukan dengan memasukkan hasil analisis ke dalam catatan, kemudian dalam kalimat penjelasan tentang temuan yang diperoleh dari hasil observasi, wawancara, dan dokumen di lapangan, dan data disusun berdasarkan fokus penelitian.

\section{Kesimpulan dan Verifikasi}

Proses selanjutnya penarikan kesimpulan sementara dari informasi yang didapat dari lapangan. Kesimpulan awal masih bersifat sementara, dan akan berubah bila tidak ditemukan bukti bukti yang kuat yang mendukung pada tahap pengumpulan data berikutnya. Selanjutnya, peneliti melakukan verifikasi dari hasil penelitian. Bila kesimpulan sementara tersebut perlu mendapat data tambahan, maka dilakukan proses pengumpulan data kembali. Setelah selesai verifikasi maka peneliti melakukan pembahasan hasil temuan dari lapangan. Penarikan kesimpulan, dalam pandangan, hanyalah sebagian dan satu kegiatan dan konfigurasi yang utuh. Singkatnya, makna-makna yang muncul dan data harus diuji kebenarannya, kekokohannya, dan kecocokannya, yakni yang merupakañ validitasnya.

\section{HASIL DAN PEMBAHASAN}

\section{Materi Sastra dalam Buku Bahasa Indonesia}

Dalam buku Bahasa Indonesia mengandung dua materi yaitu materi bahasa dan materi sastra. Pada jenjang SMP kelas VII materi sastra yang dimuat dalam buku Bahasa Indonesia meliputi puisi rakyat, cerita pendek, cerita imajinasi, dan fabel atau legenda. Pada kelas VIII materi sastra yang dimuat dalam Bahasa Indonesia meliputi puisi, buku fiksi nonfiksi, dan teks drama. Pada kelas IX materi sastra yang dimuat dalam Bahasa Indonesia meliputi karya sastra, cerita pendek, dan cerita inspiratif. Selain pada jenjang SMP.

\section{Materi Cerita Fantasi}

Pada materi kelas 7 bacaan "Mengidentifkasi Karakteristik Unsur Pembangun Cerita Fantasi" sudah relevan dengan teori sastra, karena dalam jurnal tersebut sudah dijelaskan cerita fantasi adalah teks cerita yang isinya bernuansa keajaiban dengan pemunculan tokohtokoh unik, nyaris unsur intrinsiknya sebagian besar mengandung cerita fantasi 


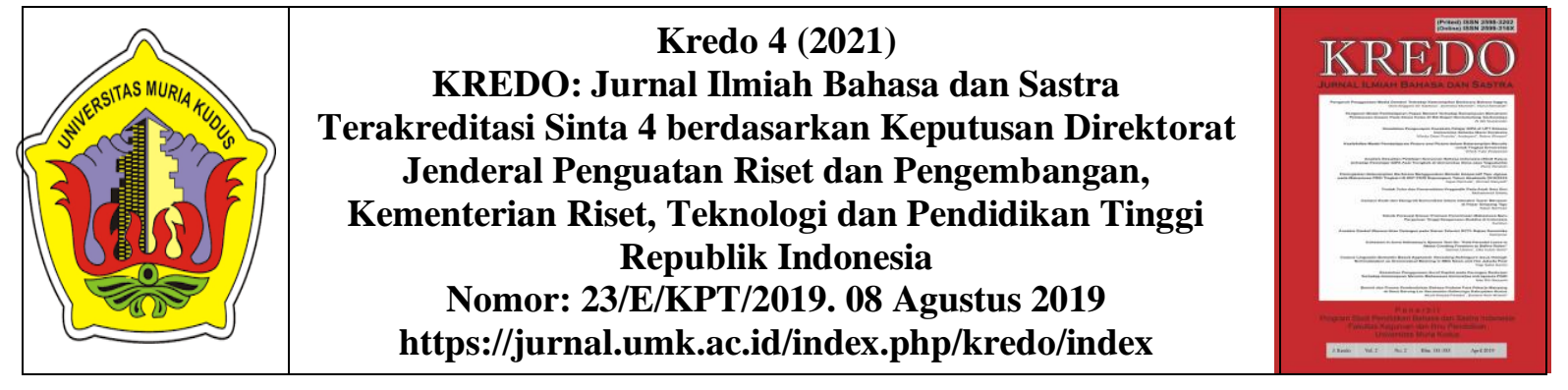

memunculkan hal-hal yang unik, aneh, dan mengherankan.

Misteri di Balik Pohon Kenari

Nono ketakutan. Kenapa dia bisa tersesat di dalam sebatang pohon kenari? Padahal, dia hanya ingin mengambil sepedanya yang tersandar di sana. Dan siapa pula anak berkulit hitam misterius yang memancingnya ke sana? Nono ingin keluar. Tapi di dalam pohon itu, membentang dunia berbeda. Dia tiba di zaman Belanda!

Itu belum seberapa. Masih banyak hal-hal aneh lain. Misalnya gadis bermata biru cantik yang bisa berubah menjadi burung kenari Gerombolan Semut Hitam. Anak Rembulan. Dunia macam apa ini? Nono ingin sekali kembali ke rumah kakek buyutnya yang nyaman di Wlingi. Tapi mungkinkah dia bisa kembali, kalau ternyata dia harus memimpin sebuah perang mencekam di dunia misteri itu?

Gambar 1. Cerita fantasi dalam buku pelajaran Bahasa Indonesia SMP

Dalam cerita teks fantasi tersebut pendidikan karakter terkandung cukup kuat dalam pemberian inspirasi kepada siswa, sehingga dapat belajar tentang apa nilai sopan santun, peduli, jujur serta bertanggungjawab. Interaksi yang terjadi antara tokoh memunculkan hal-hal di luar pemahaman logika manusia. Pemahaman tersebut disajikan dalam bentuk cerita sehingga siswa membaca kemudian mengidentifikasi unsur-unsur yang ada dalam cerita tersebut serta mencoba menceritakan kembali rangkaian peristiwa yang terjadi. Cerita fantasi yang disajikan juga cocok untuk anak SMP karena ceritanya tidak mengandung unsur kedewasaan. Ceritanya kebanyakan mengandung unsur petualangan dan siswa SMP diajak untuk berpikir melalui cerita fantasi yang disajikan. Sesuai dengan penelitian Huda (2018) bahwa karya sastra yang disajikan kepada siswa perlu mempertimbangkan usia. Dengan demikian, karya sastra tersebut akan sesuai dengan tingkat berpikir dan perkembangan moral siswa.

Pada materi teori sastra dan cerita fantasi yang disajikan relevan dengan teori sastra karena dalam jurnal tersebut dijelaskan bahwa materi sastra dalam cerita fantasi tidak memprioritaskan pada interpretasi realistis seperti mitos, legenda, dongeng, dan lebih mengkaitkan ke dalam alam selain manusia. Materi yang terdapat di buku Bahasa Indonesia kelas VII SMP lebih ke cerita khayalan yang dapat berimajinasi lebih tinggi, begitupun dengan materi yang terdapat di jurnal. Cerita fantasi tersebut lebih mengarah ke cerita kehidupan sehari-hari yang juga dikaitkan dengan khayalankhayalan sehingga menceritakan kejadian yang tidak pernah dialami di dunia.

\section{Materi Puisi Rakyat}

Kekurangan dalam materi ini adalah ketidakkonsistenan pemberian contoh materi pantun. Contoh pantun yang diberikan pada Buku Pelajaran Bahasa Indonesia kelas VII halaman 167 berbeda dengan contoh yang diberikan pada halaman 174 . Untuk contoh yang ada di halaman 167 ada 4 pantun yang lama atau pantun karya nenek moyang, sedangkan di halaman 174 ada 8 pantun (untuk isi dari pantun 1-4 sama dengan contoh pantun halaman 167 yaitu pantun karya nenek moyang) dan ditambah dengan pantun masa kini. Hanya saja tidak ada contoh penjelasan untuk menyelesaikan kegiatan pembelajaran yang terdapat dalam materi gurindam. Contoh pembahasan sangat bermanfaat untuk mempermudah siswa dalam mengaplikasikan kegiatan pembelajaran dalam buku teks. Misalnya contoh halaman 


Kredo 4 (2021)
KREDO: Jurnal Ilmiah Bahasa dan Sastra
Terakreditasi Sinta 4 berdasarkan Keputusan Direktorat
Jenderal Penguatan Riset dan Pengembangan,
Kementerian Riset, Teknologi dan Pendidikan Tinggi
Republik Indonesia
Nomor: 23/E/KPT/2019.08 Agustus 2019
https://jurnal.umk.ac.id/index.php/kredo/index

Marilah membaca puisi rakyat untuk mengenali bentuk dan memahami nilai luhur yang terkandung di dalamnya!

Pantun 1

Air surut mem

Sayur diisi ke dalam kantung.

Jangan diikuti tabiat ayam,

Bertelur sebiji riuh sekampung.

Pantun 3

Ikan nila dimakan berang-berang

Katak hijau melompat ke kiri;

Jika berada di rantau orang

Baik-baik membawa diri.

Gambar 2. Puisi rakyat dalam buku pelajaran

Bahasa Indonesia SMP

Pantun ada baiknya disesuaikan dengan tema kekinian. Meskipun secara bentuk puisi rakyat termasuk lama, isi dapat disesuaikan dengan tema yang kekinian dan sesuai dengan usia anak. Huda (2020) menyatakan bahwa bahan ajar, termasuk puisi rakyat, perlu memperhatikan usia siswa.

\section{Materi Fabel}

Dalam buku Bahasa Indonesia kelas VII materi sastra bab 6 yang menjelaskan mengenai "Mengapresiasi dan Mengkreasikan Fabel" yaitu pada point A Menjelaskan tentang Ciri Umum Cerita Fabel. Materi tersebut menggunakan KD (3.11), (4.11), (3.12), dan (4.12.) Pada point A terdapat 2 materi. Materi pada nomor 1 tentang "Mengenali Ciri Umum Fabel" dan materi nomor 2 tentang "Mengidentifikasi Jenis Fabel" akan tetapi materi tersebut dirasa masih kurang dengan KD yang digunakan, karena jumlah materi masih terlalu sedikit dibandingkan dengan KD yang digunakan, kedua materi tersebut belum merinci pada menceritakan kembali fabel atau menelaah cerita fabel.

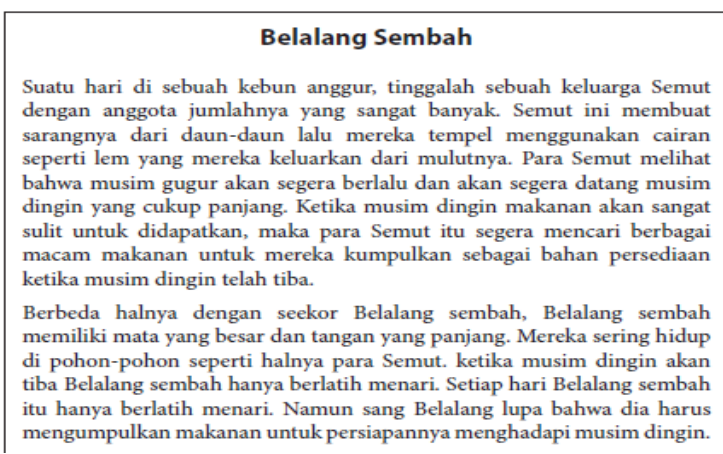

Gambar 3. Fabel rakyat dalam buku pelajaran Bahasa Indonesia SMP

Dalam buku pelajaran Bahasa Indonesia kelas VIII terdapat cerita fiksi berjudul "Penggembala Domba dan Serigala" kekurangan di dalam cerita fiksi tersebut tidak ada makna tersurat sehingga pembaca harus memahami sendiri makna dari cerita tersebut. Hal ini membuat siswa kesulitan dalam memahami makna dari cerita tersebut. Mempelajari cerpen memiliki sejumlah manfaat bagi siswa seperti memperluas perspektif siswa terhadap bidang tertentu, memungkinkan siswa untuk memikirkan proses dan hasilnya, menunjukkan gaya hidup yang berbeda, memberikan perbandingan antara budaya sendiri dan budaya lain, meningkat apresiasi terhadap sastra dan membuat siswa membaca lebih banyak cerita pendek. Tidak adanya makna tersurat dalam sebuah teks menjadikan siswa menjadi lebih termotivasi untuk mempelajari dan mencari tahu makna dari teks tersebut.

\section{Materi Teks Eksemplum}

Dalam buku pelajaran Bahasa Indonesia kelas IX ditemukan contoh yang tidak mutakhir, yaitu contoh teks pada halaman 20. Teks tersebut merupakan tulisan tahun 1992 yang menunjukan bahwa contoh teks tersebut tidak mutakhir (tidak terbaru). Selain itu, 


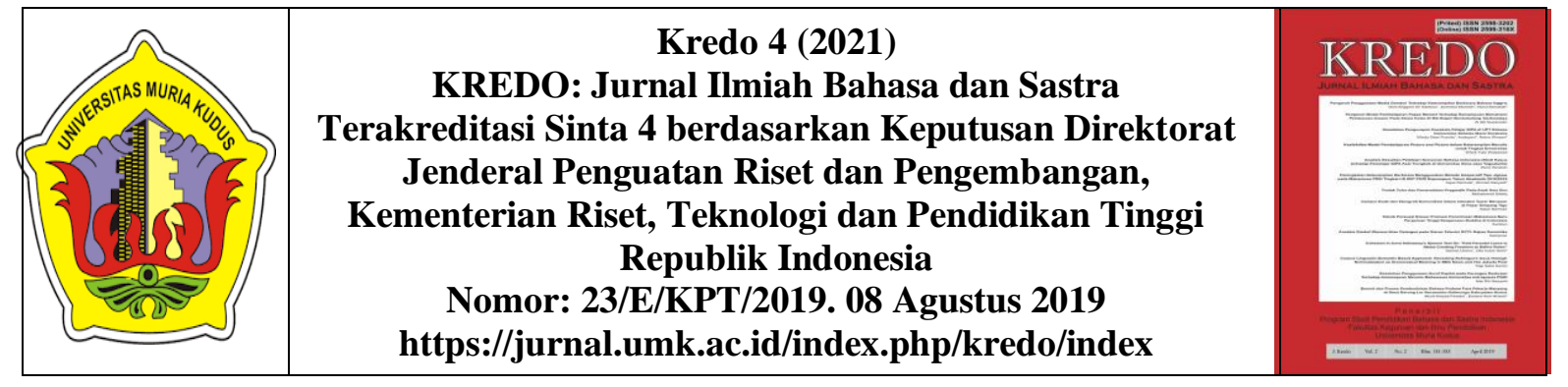

di dalam isi teks juga kurang sesuai dengan keadaan di Indonesia. Pada contoh teks tersebut ada juga orang yang berkehidupan mewah, memiliki mobil dan garasi tetapi masih tinggal di rumah susun. Di Indonesia pada umumnya yang menempati rumah susun adalah masyarakat kalangan menengah ke bawah. Bahkan, dominan masyarakat kalangan bawah. Beberapa cara untuk memberikan contoh yang tepat dalam mendeskripsikan sesuatu.

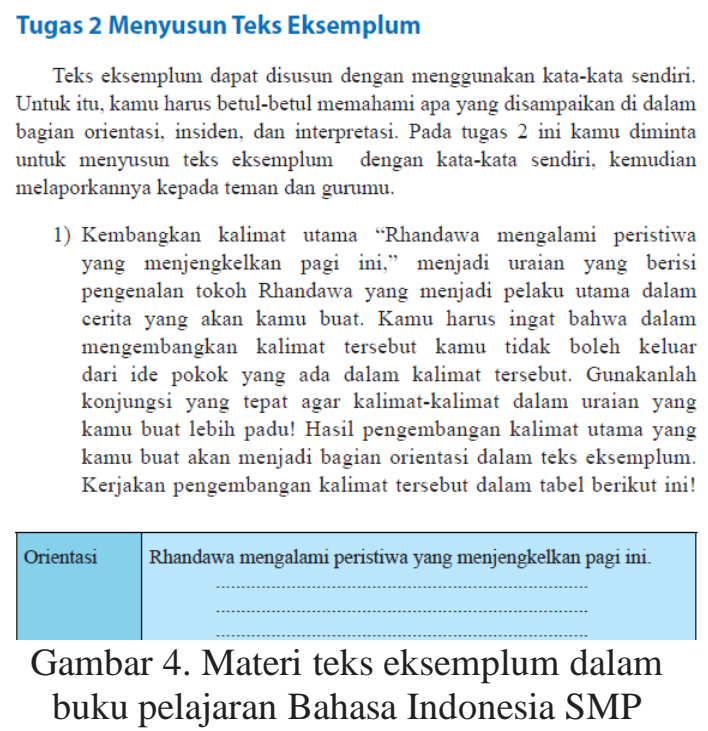

Teks eksemplum dapat disusun dengan menggunakan kata-kata sendiri. Untuk itu, kamu harus betul-betul memahami apa yang disampaikan di dalam bagian orientasi, insiden, dan interpretasi. Pada tugas 2 ini kamu diminta untuk menyusun teks eksemplum dengan kata-kata sendiri, kemudian melaporkannya kepada teman dan gurumu.

1) Kembangkan kalimat utama "Rhandawa mengalami peristiwa yang menjengkelkan pagi ini," menjadi uraian yang berisi pengenalan tokoh Rhandawa yang menjadi pelaku utama dalam cerita yang akan kamu buat. Kamu harus ingat bahwa dalam mengembangkan kalimat tersebut kamu tidak boleh keluar dari ide pokok yang ada dalam kalimat tersebut. Gunakanlah konjungsi yang tepat agar kalimat-kalimat dalam uraian yang kamu buat lebih padu! Hasil pengembangan kalimat utama yang kamu buat akan menjadi bagian orientasi dalam teks eksemplum. Kerjakan pengembangan kalimat tersebut dalam tabel berikut ini!

Gambar 4. Materi teks eksemplum dalam buku pelajaran Bahasa Indonesia SMP

\section{Materi Puisi}

Buku pelajaran Bahasa Indonesia kelas VIII terdapat contoh puisi dan soal tentang mengidentifikasi puisi, tetapi di dalam contoh puisi tersebut tidak terdapat contoh materi tata cara mengidentifikasi puisi. Dalam contoh tersebut tidak ada penjabaran mengenai materi puisi. Hal ini membuat siswa kesulitan dalam memahami materinya. Cara mengidentifikasi puisi kemudian dijabarkan dengan mimik yang menjiwai sesuai dengan isi puisi.

Dalam materi teks puisi dengan sub-materi Membaca Puisi dapat dikatakan tidak relevan. Siswa diminta langsung menunjukkan kemampuan membaca puisinya tanpa diberi contoh oleh guru yang sesuai dengan unsur-unsur penyusun puisi. Puisi tersebut juga terdapat kata-kata yang sulit dipahami oleh siswa. Posisi puisi dalam pengajaran sastra tidak sederhana. Siswa cenderung menunjukkan sikap negatif terhadapnya dan menganggapnya tidak dapat dipahami dan jauh dari dunia saat ini. Pada Bab 8 halaman 255 terdapat teks puisi yang berjudul "Ibu" karya D. Zamawi Imron. Di dalam puisi tersebut siswa diminta untuk membaca puisi dengan memperhatikan vokal, ekspresi, dan intonasi pada akhir pembacaan puisi teman yang lain memberikan penilaian yang telah disediakan.

Dalam materi teks puisi dengan sub-materi membaca puisi dapat dikatakan tidak relevan. Materi puisi tersebut terdapat kata-kata yang kurang sesuai dengan perkembangan psikologi remaja dan juga terdapat kata yang sulit dipahami oleh siswa. Di dalam tugas siswa yaitu menilai temannya dalam pembacaan puisi dengan mengisi kolom yang tersedia, siswa akan mengalami kesulitan dalam pengisian nilai dikarenakan hanya ada keterangan rentang nilai tidak terdapat keterangan aspek penilaian atau nilai maksimal. Sedangkan di dalam kolom tersebut terdapat kolom aspek seperti vokal, ekspresi, intonasi, dan masih terdapat kolom 


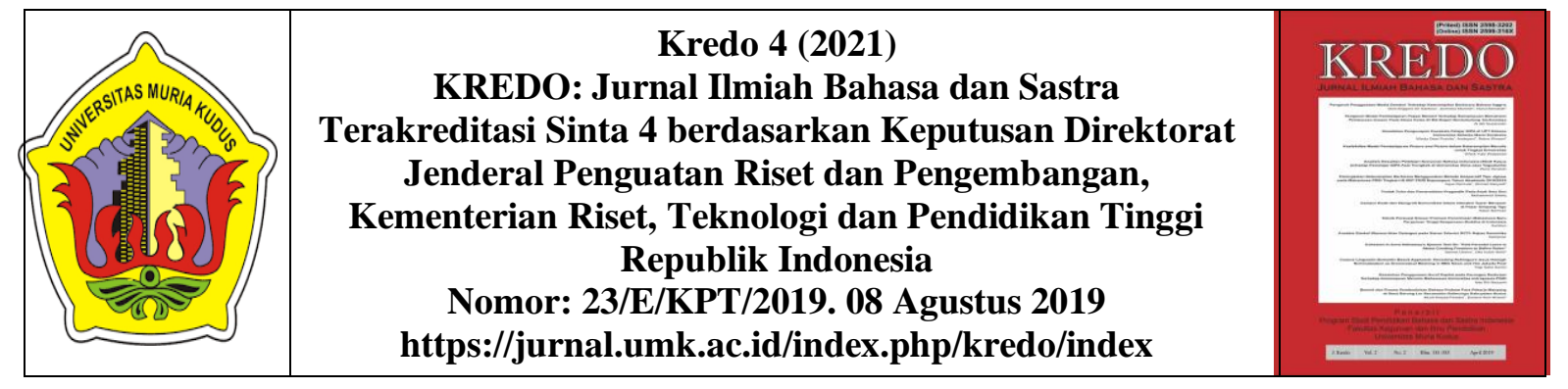

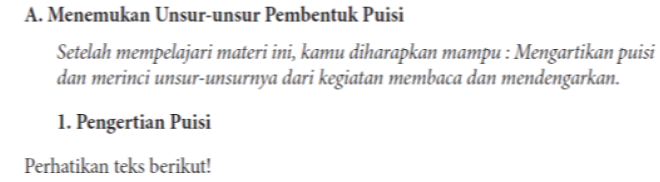

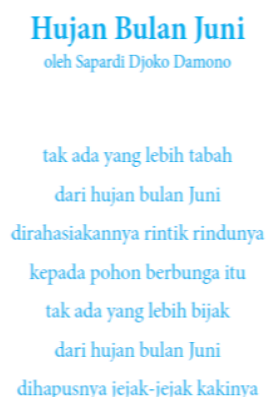

Gambar 5. Materi puisi eksemplum dalam buku pelajaran Bahasa Indonesia SMP

Kata-kata dan kalimat memberikan kesenangan besar pada orang tersebut dan penggunaannya untuk menciptakan antusiasme dan emosi yang berbeda pada orang tersebut, berbagai makna, peristiwa, dan seni kata, kontribusi suara dan ritme memungkinkan puisi rakyat dalam harmoni fonetik dan semantik. Keberhasilan membaca dan makna dalam bahasa sampel liris yang mencerminkan emosi alami dan antusiasme penyair memperkuat kekuatan puisi rakyat semakin. Apalagi kekuatan ini mencapai puncak dalam karya disertai dengan musik yang dikomposisikan.

Pada Bab 8 halaman 257 terdapat Musikalisasi puisi yang berjudul "Ketika Tangan dan Kaki Berkata" Lirik dibuat oleh Taufiq Ismail dan Lagu dari Chrisye. Siswa diminta untuk mendengarkan rekaman lagu dari guru, setelah itu siswa diminta untuk mencari lagu untuk dijadikan sebuah musikalisasi puisi.

\section{Materi Cerita Fiksi}

Pada buku pelajaran Bahasa Indonesia kelas VIII terdapat contoh cerita fiksi dan soal untuk mengidentifikasi cerita fiksi tersebut, tetapi di dalam penjelasan materi untuk mengidentifikasi cerita fiksi tidak lengkap. Di dalam penjelasan tidak langsung berada di bawahnya tetapi diselingi dengan contoh soal lainnya. Hal ini membuat siswa kesulitan dalam memahami materi. Visi tentang bagaimana pengajaran sastra harus dilakukan secara alami melihat bahwa melalui pelajaran sastra dapat menjdi kritikus sastra yang baik, pelajaran disusun sedemikian rupa sehingga menekankan interpretasi yang benar. Makna yang diambil dari atau disimpulkan dari sumber-sumber tertentu. Intruktur memainkan peran penting memberikan analisis makna yang diterima atau benar untuk karya sastra. Jelas, makna dianggap tetap dan siswa diharapkan untuk sampai pada makna yang dapat dijelaskan dari teks atau penulis.

\footnotetext{
1. Ungkapan sebagai Unsur Kebahasaan dalam Buku Fiksi

Membaca buku tidak sekadar memperoleh sejumlah informasi dan memperluas wawasan. Membaca buku fiksi khususnya, dapat menemukan hal lain yang tidak kalah menarik. Misalnya tentang diksi ataupun ragam bahasanya. Perhatikan cuplikan berikut!

Maka, tergambarlah pula di muka Hanafi ke masa yang sudah-sudah.Zaman hubungan cintanya yang berhingga-hingga. Hidup bermanis-manis pun berlamalama ia kenangnya. Tahulah Hanafi sekarang: Rafiah, intan yang belum digosok. Sayang, ia tidak pandai menggosoknya hingga barang itu dibanting-banting, seolah tak berharga. Sementara Corrie, berlian yang sudah digosok, harganya tidak ternilainilai, tapi suami yang celaka tak pandai memakainya, dan enyahlah harta itu dari rangkulannya. Hanafi menyesali dirinya tidak berhingga-hingga. Maka ditutupnyalah mukanya dengan kedua belang tahannya, lalu menangis mengusak-ngisak sambi berseru dalam hatinya, "Oh, Corrie, Corrie istriku! Di manakah engkau sekarang. Lihatlah suamimu menyadari untung, lekaslah kembali, supaya kita menyambung hidup kembali seperti dulu." (Novel Salah Asuhan Balai Pustaka, 2010, Abdul Muis).

Gambar 6. Materi fiksi dalam buku pelajaran Bahasa Indonesia SMP

Pada buku pelajaran Bahasa Indonesia kelas VII juga terdapat cerita fiski berjudul "Pak Lebay". Kekurangan di dalam cerita fiksi tersebut adalah
} 


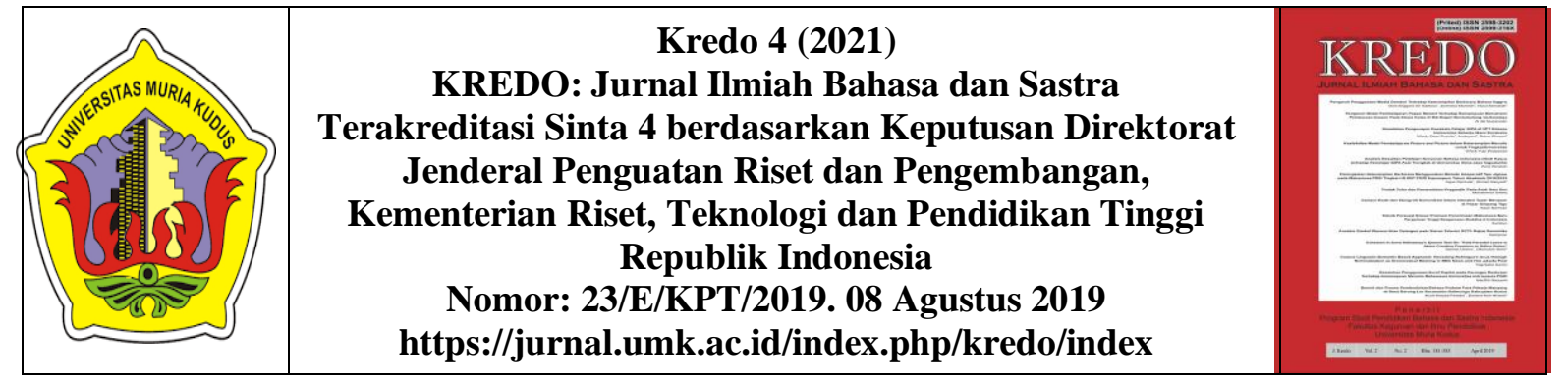

format dari cerita tersebut dibagi menjadi beberapa bagian sehingga cenderung seperti paragraf bukan seperti cerita.

\section{Materi Cerita Pendek}

Pada buku pelajaran Bahasa Indonesia kelas VIII terdapat cerita pendek berjudul "Pak Adil Mencari Keadilan". Kekurangan di dalam cerita pendek tersebut adalah penggunaan dalan cerita pendek tersebut ada yang tidak menggunakan bahasa baku dan ada penggunaan tanda baca yang tidak sesuai dengan Kamus Besar Bahasa Indonesia dan Pedoman Umum Ejaan Bahasa Indonesia. Kualitas sebuah teks mempengaruhi motivasi belajar pembaca atau siswa sehingga dalam penulisan teks harus benar.

Kearifan lokal pada cerita rakyat dapat menjadi sarana pembelajaran dalam mengenalkan, melestarikan, dan mempromosikan kearifan lokal di lingkungan (Samur, Tops, and Koole 2017), (Monaghan and Roberts 2019). Selain itu, dapat digunakan sarana untuk meniru nilai-nilai positif untuk diterapkan dalam kehidupan sehari-hari. Dengan karya sastra yang mengandung kearifan lokal dapat menciptakan pembelajaran inovatif. Melalui teks cerita pendek, seseorang mencoba menyampaikan pesan moral kepada pembacanya. Sastra dapat digunakan sebagai alternatif pembelajaran karakter untuk mencapai ketegasan sikap, matang dalam berpikir, dan sadar multikulturalisme.

Pada buku pelajaran Bahasa Indonesia kelas VIII bab 4 halaman 127 dan halaman 139 dalam materi tersebut dijelaskan bahwa siswa diminta untuk membandingkan nilai dan kebahasaan hikayat dengan cerpen lalu mengembangkan cerita rakyat ke dalam bentuk cerpen. Dalam hal ini kemampuan siswa dalam membaca hikayat dan cerpen dengan dituntut pemahaman yang lebih jeli serta teliti untuk menyelesaikan tugas yang diberikan dengan baik dan benar, karena dalam hal membandingkan dan menceritakan kembali membutuhkan konsentrasi yang lebih ketika membaca dan memahami terhadap kedua karya sastra tersebut.

\section{Materi Anekdot}

Teks anekdot terdapat struktur serta ciri kebahasaan dalam teks anekdot. Dalam teks anekdot terdapat ciri kebahasaan yang terdiri dari kalimat yang menyatakan masa lalu, kata kerja aksi, kalimat perintah, kalimat seru, pernyataan restoris, konjungsi. Struktur dalam teks anekdot terdiri dari abstraksi, orientasi, krisis, reaksi, dan koda. Pada Bab 3 halaman 82 dalam materi tersebut dijelaskan bahwa siswa diminta untuk menganalisis ciri kebahasaan yang ada di dalam teks anekdot.

Dalam materi teks anekdot dengan sub-materi berupa menganalisis ciri kebahasaan dalam teks anekdot dapat dikatakan relevan, karena di dalam buku tersebut disertai penjelasan mengenai apa saja ciri kebahasaan yang terdapat dalam suatu teks anekdot beserta contohnya, sehingga siswa dapat mengerjakan tugas atau latihan pada bagian ini, karena siswa sudah mengetahui materi tentang ciri kebahasaan teks anekdot. Teks anekdot terdapat ciri kebahasaan yang terdiri dari kalimat yang menyatakan masa lalu, kata kerja aksi, kalimat perintah, kalimat seru, pernyataan restoris, konjungsi. Pada Bab 3 halaman 93 dalam materi tersebut dijelaskan bahwa siswa diminta untuk menganalisis struktur yang ada di dalam teks anekdot. 


Kredo 4 (2021)
KREDO: Jurnal Ilmiah Bahasa dan Sastra
Terakreditasi Sinta 4 berdasarkan Keputusan Direktorat
Jenderal Penguatan Riset dan Pengembangan,
Kementerian Riset, Teknologi dan Pendidikan Tinggi
Republik Indonesia
Nomor: 23/E/KPT/2019. 08 Agustus 2019
https://jurnal.umk.ac.id/index.php/kredo/index

\section{Materi Hikayat}

Hikayat merupakan cerita Melayu yang menonjolkan unsur penceritaan berciri kemustahilan dan kesaktian tokohtokohnya. Kegiatan mendengarkan hikayat memiliki banyak manfaat. Siswa akan mengetahui tentang budaya, moral, dan nilai-nilai kehidupan lain. Dari cerita hikayat, kita dapat memetik nilai-nilai kehidupan sebagai cermin bagi kehidupan kita. Pada Bab 4 terdapat contoh hikayat dan soal tentang mengidentifikasi isi hikayat, tetapi di dalam pembacaan hikayat diperlukan konsentrasi pada cerita yang didengar agar dapat mencatat tema atau inti ceritanya.

Berdasarkan pemetaan tersebut ditemukan bahwa pemetaan materi sastra dalam buku pelajaran Bahasa Indonesia Sekolah Menengah Pertama telah meliputi genre sastra secara lengkap, yaitu puisi, prosa, dan drama. Namun, sebaran masing-masing subgenre belum seimbang. Genre prosa memiliki jumlah yang lebih banyak dibandingkan dengan genre lain. Genre prosa terdistribusi ke dalam materi cerita fantasi, fabel, cerita pendek, fiksi, dan teks eksemplum. Genre puisi menduduki posisi kedua dengan distribusi puisi rakyat dan puisi. Genre drama memiliki sebaran terendah karena hanya ada satu materi sastra bergenre drama.

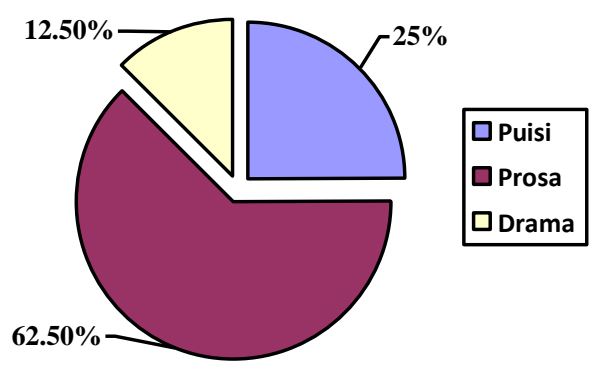

Gambar 7. Persentase Materi Sastra
Gambar 7 menunjukkan bahwa sebaran materi sastra dalam buku pelajaran Bahasa Indonesia Sekolah Menengah Atas belum seimbang. Materi sastra didominasi oleh genre prosa, sedangkan genre drama sangat sedikit. Hal ini bisa saja disebabkan asumsi bahwa drama memerlukan waktu dan ruang yang lebih banyak karena praktik pementasan. Akan tetapi, asumsi tersebut tidak sepenuhnya tepat. Praktik pementasan dan latihan dapat dilakukan dalam bentuk penugasan, sehingga tidak mengurangi porsi materi.

Apabila komponen materi sastra disandingkan dengan materi bahasa dalam buku pelajaran Bahasa Indonesia, akan menunjukkan hasil bahwa materi sastra hanya sebesar $37,8 \%$, sedangkan sisanya adalah materi bahasa. Kesimbangan ini juga perlu diperhatikan sehingga tidak ada ketimpangan kompetensi berbahasa dan bersastra dalam diri siswa. Hal ini sesuai dengan penelitian Huda (2019) bahwa keseimbangan materi bahasa dan sastra sangat diperlukan oleh siswa. Materi bahasa salah satunya membuat siswa mampu berkomunikasi dengan baik, sedangkan materi sastra membuat siswa memiliki kehalusan budi dan kepribadian yang baik.

\section{SIMPULAN}

Materi sastra dalam buku pelajaran Bahasa Indonesia terbitan Kementerian Pendidikan dan Kebudayaan untuk jenjang Sekolah Menengah Pertama kelas VII terdiri dari cerita fantasi, puisi rakyat, dan fabel. Kelas VIII terdiri dari puisi, cerita pendek, drama, dan fiksi. 


Kredo 4 (2021)
KREDO: Jurnal Ilmiah Bahasa dan Sastra
Terakreditasi Sinta 4 berdasarkan Keputusan Direktorat
Jenderal Penguatan Riset dan Pengembangan,
Kementerian Riset, Teknologi dan Pendidikan Tinggi
Republik Indonesia
Nomor: 23/E/KPT/2019. 08 Agustus 2019
https://jurnal.umk.ac.id/index.php/kredo/index

Kelas IX terdiri dari teks eksemplum. Materi sastra dalam buku pelajaran Bahasa Indonesia Sekolah Menengah Pertama berjumlah 8 dari jumlah total 26 materi. Dengan demikian, materi sastra dalam buku pelajaran Bahasa Indonesia memiliki persentase sebanyak $37,8 \%$.
Saran bagi pemerintah yang membawahi permasalahan kurikulum adalah perlu adanya keseimbangan antara materi bahasa dan materi sastra. Selain itu, keseimbangan distribusi materi dalam genre tertentu juga perlu menjadi perhatian.

\section{DAFTAR PUSTAKA}

Barnes, Tia Navelene, and Kathleen McCallops. 2019. "Perceptions of Culturally Responsive Pedagogy in Teaching SEL." Journal for Multicultural Education 13(1): 70-81.

Bezemer, Jeff, and Gunther Kress. 2008. "Writing in Multimodal Texts: A Social Semiotic Account of Designs for Learning." Written Communication 25(2): 16695.

Bogodistov, Yevgen, Moritz Botts, and Florian Schlatterer. 2019. "Values Congruence in Multicultural Groups : The Causal Mapping Method." Journal for Multicultural Education 13(1): 33-50.

Brooks, Maneka Deanna. 2016. “"Tell Me What You Are Thinking': An Investigation of Five Latina LTELs Constructing Meaning with Academic Texts." Linguistics and Education 35: 1-14. http://dx.doi.org/10.1016/j.linged.2016.03.001.

Collette, Tyler L, and Richard L Miller. 2018. "Cross-Cultural Differences in Children' S Preferences for Moral Tales." International Journal of Developmental Science 12: $175-87$.

Darvin, Jacqueline. 2018. "Becoming a More Culturally Responsive Teacher by Identifying and Reducing Microaggressions in Classrooms and School Communities." Journal for Multicultural Education 12(1): 2-9.

Haneda, Mari. 2014. "From Academic Language to Academic Communication: Building on English Learners' Resources." Linguistics and Education 26: 1-10. http://dx.doi.org/10.1016/j.linged.2014.01.004.

Huang, Ju Chuan. 2017. "What Do Subject Experts Teach about Writing Research Articles? An Exploratory Study." Journal of English for Academic Purposes 25: $18-29$. http://dx.doi.org/10.1016/j.jeap.2016.10.004.

307 | Jurnal Kredo Vol. 4 No. 22021 


Kredo 4 (2021)
KREDO: Jurnal Ilmiah Bahasa dan Sastra
Terakreditasi Sinta 4 berdasarkan Keputusan Direktorat
Jenderal Penguatan Riset dan Pengembangan,
Kementerian Riset, Teknologi dan Pendidikan Tinggi
Republik Indonesia
Nomor: 23/E/KPT/2019. 08 Agustus 2019
https://jurnal.umk.ac.id/index.php/kredo/index

Huda, Miftakhul. 2018. "Strategi Berpikir Integratif Dalam Pembelajaran Membaca Lintas Kurikulum Di Sekolah Dasar.” Jurnal Kredo 1(2): 26-35.

2019a. "Dinamika Sosial Dalam Novel Pencari Harta Karun Dan Five on a Hike Together." Bahasa dan Seni: Jurnal Bahasa, Sastra, Seni, dan Pengajarannya 47(1): 36-43.

- 2019b. "Managerial Communication System for the Operation of Learning Acceleration Programs.” Jurnal Iqra' : Kajian Ilmu Pendidikan 4(2): 168-81. 206.

Huda, Miftakhul, Erry Widya Kustanti, and Ani Rufiah. 2019. "Peningkatan Pemilihan Materi Ajar Melalui Telaah Buku Teks Bagi Guru Bahasa Indonesia Di SMP Muhammadiyah Surakarta." Warta LPM 22(2): 110-19.

Huda, Miftakhul, Markhamah, and Atiqa Sabardila. 2011. "Model Kurikulum Dan Media Pembelajaran Bahasa Indonesia Pada Program Percepatan Belajar Di SMA Negeri 3 Surakarta." Jurnal Penelitian Humaniora 12(1): 32-42.

Huda, Miftakhul, and Dini Restiyanti Pratiwi. 2020. Kajian Buku Teks Bahasa Dan Sastra Indonesia. I. Surakarta: Muhammadiyah University Press.

Huda, Miftakhul, Abdul Syukur, and Wahyudi Siswanto. 2020. "Literation of Kebinekaan in Indonesian Text Books for Senior High Schools." International Journal of Innovation, Creativity and Change 12(2): 278-95.

Israfilov, Nail, Oksana Borisova, and Oxana Kartashova. 2020. "Motivation and Employee Effectiveness in Online Learning Environments : Leadership Strategies of New Generation and Emotional Intellect." International Journal of Emerging Technologies in Learning (iJET) 15(9): 258-79.

Jalil, Habibah Ab, Aini Marina Ma'rof, and Rosmaria Omar. 2019. "Attitude and Behavioral Intention to Develop and Use MOOCs among Academics." International Journal of Emerging Technologies in Learning (iJET) 14(24): 31-41.

Jessel, John et al. 2011. "Different Spaces: Learning and Literacy with Children and Their Grandparents in East London Homes." Linguistics and Education 22(1): 3750. http://dx.doi.org/10.1016/j.linged.2010.11.008.

Kurhila, Salla, and Lari Kotilainen. 2020. "Student-Initiated Language Learning Sequences in a Real-World Digital Environment." Linguistics and Education 56: 1- 


Kredo 4 (2021)
KREDO: Jurnal Ilmiah Bahasa dan Sastra
Terakreditasi Sinta 4 berdasarkan Keputusan Direktorat
Jenderal Penguatan Riset dan Pengembangan,
Kementerian Riset, Teknologi dan Pendidikan Tinggi
Republik Indonesia
Nomor: 23/E/KPT/2019. 08 Agustus 2019
https://jurnal.umk.ac.id/index.php/kredo/index

11. https://doi.org/10.1016/j.linged.2020.100807.

Lina, Markauskaite. 2020. "Learning for Professional Expertise: Towards New Ways of Conceptualising Conceptual Change." International Journal of Educational Research 103: 3-9.

Liu, Zhi-jiang, Natalia Tretyakova, Vladimir Fedorov, and Marina Kharakhordina. 2020. "Digital Literacy and Digital Didactics as the Basis for New Learning Models Development." International Journal of Emerging Technologies in Learning (iJET) 15(14): 4-18.

Lo, Jose Manuel. 2017. "Children 'S Literature and Nation Building: The Basque." Children's Literature in Education.

Malluhi, Hazar Hekmat, and Nayel Musa Alomran. 2019. "Family Volunteers as Alternative Future Resources: School Leaders ' Beliefs and Practices." International Journal of Emerging Technologies in Learning (iJET) 14(10): 88115.

Marcus, Valerie Bukas et al. 2019. "Promoting Students' Generic Skills with the Integration of E-Service Learning Platform." International Journal of Emerging Technologies in Learning (iJET) 14(20): 4-17.

Martínez, Inmaculada García -, and Pedro Tadeu. 2018. "The Influence of PedagogicalLeadership on the Construction of ProfessionalIdentity." Journal of Social Studies Education Research 9(3): 145-62.

Monaghan, Padraic, and Seán G Roberts. 2019. "Cognitive in Fluences in Language Evolution: Psycholinguistic Predictors of Loan Word Borrowing." Cognition 186: $147-58$.

Moto, Sangutai, Thanin Ratanaolarn, Somkiat Tuntiwongwanich, and Paitoon Pimdee. 2018. "A Thai Junior High School Students' 21 St Century Information Literacy, Media Literacy, and ICT Literacy Skills Factor Analysis." International Journal of Emerging Technologies in Learning (iJET) 13(9): 87-106.

Muakibatul Hasanah. 2012. "Model Cerita Fiksi Kontemporer Anak-Anak Untuk Pengembangan Kemahirwacanaan Siswa Kelas 5 Sekolah Dasar.” Litera 11(1): 98108.

Mudiono, Alif. 2019. "Teaching Politeness for Primary School Students in Indonesia: Mediating Role of Self Efficacy and Self Esteem of Learners." Journal of Social $\begin{array}{llll}\text { Studies } & \text { Education } & \text { Research } & \text { 427-45. }\end{array}$

309 | Jurnal Kredo Vol. 4 No. 22021 


Kredo 4 (2021)
KREDO: Jurnal Ilmiah Bahasa dan Sastra
Terakreditasi Sinta 4 berdasarkan Keputusan Direktorat
Jenderal Penguatan Riset dan Pengembangan,
Kementerian Riset, Teknologi dan Pendidikan Tinggi
Republik Indonesia
Nomor: 23/E/KPT/2019. 08 Agustus 2019
https://jurnal.umk.ac.id/index.php/kredo/index

Neumann, Heike, and Kim Mcdonough. 2014. "Exploring the Relationships among Student Preferences, Prewriting Tasks, and Text Quality in an EAP Context." Journal of English for Academic Purposes 15: 14-26. http://dx.doi.org/10.1016/j.jeap.2014.05.002.

Rahmouni, Mohieddine, and Mohammed Abdulaziz. 2020. "Teachers' Practices and Children' S Motivation Towards Science Learning in MENA Countries: Evidence from Tunisia and UAE." International Journal of Educational Research 103(May): 1-16. https://doi.org/10.1016/j.ijer.2020.101605.

Ranker, Jason. 2019. “Children' S Sign-Making and Construction of Signifying Chains in Relation to Texts: Book Interactions as Discursive Processes." Linguistics and Education 51: 46-58. https://doi.org/10.1016/j.linged.2019.04.001.

Samur, Dalya, Mattie Tops, and Sander L Koole. 2017. "Does a Single Session of Reading Literary Fiction Prime Enhanced Mentalising Performance? Four Replication Experiments of Kidd and Castano (2013)." Cognition and Emotion: 115. http://dx.doi.org/10.1080/02699931.2017.1279591.

Subyantoro. 2007. "Model Bercerita Untuk Meningkatkan Kecerdasan Anak : Aplikasi Ancangan Psikolinguistik." Humaniora 19(3): 261-73.

Tabatadze, Shalva, and Natia Gorgadze. 2016. "Selective Intercultural Sensitivity to Different Sources of Cultural Identity: Study of Intercultural Sensitivity of Students in Georgia Teacher Education Programs." Journal for Multicultural Education 12(1): $35-49$.

Tarman, Bülent, and İsmail Acun. 2010. "Social Studies Education and a New Social Studies Movement.” Journal of Social Studies Education Research 1(1): 1-16.

Thi Nguyen, Hong-Thu. 2020. "Communication Skills and Reflection Practice in Smart English Teaching and Learning Environment A Case Study." International Journal of Emerging Technologies in Learning (iJET) 15(17): 221-37.

Zhdanko, Anna. 2019. "Identification of Cognitive Manipulations That Have The Greatest Impact on Students in The Internet." International Journal of Cognitive Research in Science, Engineering and Education (IJCRSEE) 7(1): 35-42. 